\title{
Teaching of Portuguese to the deaf: an integrative literature review
}

\author{
Michele Elias de Carvalho' \\ https://orcid.org/0000-0002-6902-7100 \\ Wanilda Maria Alves Cavalcanti ${ }^{1}$ \\ https://orcid.org/0000-0003-2785-5554 \\ Josiane Almeida da Silva ${ }^{1}$ \\ https://orcid.org/0000-0002-9480-5461
}

Universidade Católica de Pernambuco, Recife, Pernambuco, Brasil.

Conflict of interests: Nonexistent

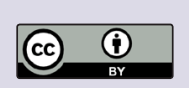

Received on: August 12, 2018

Accepted on: February 26, 2019

Corresponding address:

Michele Elias de Carvalho

Rua Dom Bosco, 546 - Ap. 402 ,

B. Boa Vista

CEP: 50070-070 - Recife, Pernambuco,

Brasil

E-mail: michelejoaos@yahoo.com.br

\section{ABSTRACT}

Purpose: to identify the contributions of scientific research with a view to overcoming the barriers in the teaching and learning process of the written Portuguese Language for deaf students.

Methods: an integrative literature review of the articles published between 2012 and 2017 available in the electronic databases: Capes and Scielo, was conducted. To select the articles, descriptors were combined: Teaching, "Portuguese Language", Portuguese, deaf and deafness. Articles present in both databases, research whose focus was the teaching of Portuguese to higher education deaf students, articles that did not deal with Portuguese language teaching to the deaf, articles unavailable in Portuguese, were the exclusion criteria. Articles that addressed, somehow , Portuguese language teaching to the deaf, complete and published between the years of 2012 and 2017 were included.

Results: 133 articles were found, 16 being selected after applying the inclusion and exclusion criteria. These studies, for the purpose of analysis, were categorized into types, being: experimental, bibliographic, documentary, ethnographic, action research, among others.

Conclusion: the deaf still face several barriers for acquiring the written Portuguese language, however, the scholars, from their field of action, propose some strategies which can contribute to overcome them, such as: policy review, early acquisition of Libras, use of digital technologies in the classroom.

Keywords: Deafness; Language; Teaching 


\section{INTRODUCTION}

The process of acquisition of the Portuguese language by deaf students still represents a very fertile field of research, since, even after the legal guarantee ${ }^{1,2}$ of bilingual education, these students continue to face difficulties to achieve proficiency in the use of writing.

In this sense, many scholars, from their theoretical perspectives, seek to find the reasons that lead the deaf students not to take full ownership of this written language. A number of researches have been carried out to investigate the linguistic barriers present in these students' lives, which end up hindering the process of schooling, such as deaf children who, because they are sons and daughters of hearing parents, do not start the process of acquiring a first language in the early years of their life and therefore have more difficulty learning a second language in the school process ${ }^{3}$ or even the need for teachers as well as schools to rethink their practices in order to offer bilingual education to which they are entitled ${ }^{4-12}$.

Each educational philosophy adopted by educational systems has in its core conceptions of language, subject and, consequently, teaching. In bilingual educational philosophy, language is conceived within an interactionist, dialogical, and functional perspective in which subjects are seen as social authors/constructors, active subjects that, dialogically, construct themselves and are constructed in the text, considered the very place of interaction and constitution of interlocutors ${ }^{13,14}$. In this conception, the deaf subject is no longer seen as someone who needs to be corrected in order to have access to the majoritarian language, starting to be conceived within a socio-anthropological view ${ }^{15,16}$ in which what they lack, hearing, is not characterized as an obstacle to the acquisition of a language, since they can acquire a sign language. Deafness, in this context, comes to be understood as a socio-cultural linguistic difference, since, due to the auditory deficit, they do not naturally acquire an oral-auditory language shared by the hearing. In this way, they will construct their identity/ subjectivity through visual experiences, sign language being the symbolic system that allows the mediation ${ }^{17}$ of these subjects with the world that surrounds them.

The use of sign language constitutes the main means of social interaction for the deaf person and plays a very important role in the bilingual school environment, aiming to occupy the language space of instruction. This is due to the fact that deaf people can learn naturally, in the case of children of deaf parents, and/or in contact with other deaf adults, in the case of children of hearing parents.

The teaching of Portuguese, preferably in written form, as a second language is justified for being the one that circulates in the country and is present in all spheres of society, making it necessary for the deaf, among other things, to have access to knowledge historically constructed by humanity that is preserved through writing.

Considering the legal guarantees and benefits indicated by scholars in the area of language acquisition in relation to the offer of bilingual education for the deaf, as well as the finding that they, in the majority, still present difficulties to appropriate the written Portuguese language, the present study raises the question: what have the scientific studies on the subject in the last five years indicated in terms of proposals or interventions to overcome these difficulties?

In order to answer this question, an integrative review of the literature was carried out, since this methodology enables the authors to summarize previous studies with the purpose of informing the readers of the state of the art of the research area. It also identifies relationships, contradictions, gaps and inconsistencies in the literature, as well as suggestions for solving problems ${ }^{18}$.

The development of this study was motivated by the fact that this subject is part of the field of theoreticalpractical studies of the research line Acquisition, Development and Language Disorders in their Various Manifestations of the Post-Graduate Program in Language Sciences at UNICAP - to which researchers are linked. In this sense, it is extremely important to broaden the reflections on the subject, in order to move towards overcoming existing barriers in the process of acquisition of writing in Portuguese by deaf students.

In this context, the main objective of this article is to identify the contributions of scientific researches with a view to overcoming barriers in the process of teaching and learning written Portuguese (PL) for deaf students.

\section{METHODS}

In order to carry out a survey of the studies that deal with the topic of Portuguese Language (PL) teaching for the deaf, the electronic databases Capes Portal and Scielo were selected, since these databases index journals that provide scientific quality articles.

Initially, the articles were selected through an advanced search in which the following descriptors were combined: teaching, "Portuguese Language", Portuguese, deaf and deaf with the Boolean operator 
and. At that time, it was also used as a filter to select the articles to be analyzed from the years 2012 to 2017 . It is worth mentioning that the publications of the year 2012 were part of this study because the searches were carried out between the months of October and November of 2017.

In the initial phase of the research, using the descriptors as well as the filter, 107 articles were selected on Capes Portal of journals and 26 on Scielo, totaling 133 articles. After applying the inclusion and exclusion criteria, 16 articles remained to carry out the present review.

In order to select the articles, the following exclusion criteria were used: 1 . articles present in both databases; 2. research focusing on the teaching of PL for deaf students in higher education; 3 . articles that did not deal with Portuguese language teaching for deaf people; 4. articles not available in Portuguese. And the inclusion criteria: articles that addressed, in some way, the teaching of Portuguese Language for the deaf, complete and published between the years of 2012 and 2017.

In order to apply the inclusion and exclusion criteria, initially, the works available in the Portuguese Language were selected. Thus, a research did not meet the criteria listed. Subsequently, the exploratory reading ${ }^{5}$ of the titles of the articles was carried out in order to identify those that were present in both data bases. During this stage, 64 articles were excluded, as they appeared in both databases. Then, also through an exploratory reading of the abstracts, it was verified which studies addressed the theme of the research. Thus, 51 papers were excluded.

In the next moment, those whose focus had been the teaching of the Portuguese Language for Higher Education students were observed. At that time, 1 work with this profile was found. After this stage, a complete reading of the last 16 articles was carried out in order to verify which of them actually contemplated the objectives of the research, being verified that these should be part of the review because they met the criteria initially listed.

After this selection, the articles were read analytically to identify the focus adopted by the authors on the theme. Then, through an interpretive reading, the contributions of the scientific researches were identified with a view to overcoming the barriers in the teaching and learning process of the written Portuguese Language (PL) for deaf students.

For the purposes of analysis, the researches were categorized according to the number of publications per year (Figure 1), the type of research (Figure 2), the thematic axis (Figure 3), the periodicals and the area of action/training of the researchers (Figure 4). Other categorization criteria could have been used, however, due to the limited space of an article, there is no way to exhaust all possibilities, nor would it be the intention of this study.

In relation to the classification of the types ${ }^{19}$ of the researches, the system adopted takes into account the research environment, the theoretical approach and the techniques of data collection. In this sense, scientific productions can be: bibliographical, which are based on material already published; documental, when they use all sorts of documents, designed for different purposes, internal to the organizations; experimental, which consists in determining an object of study, selecting the variables capable of influencing it and defining the forms of control and observation of the effects that the variables produce on the object; actionoriented research ${ }^{20}$, conceived and carried out in strict association with an action or with the resolution of a collective problem in which all researchers and participants are involved in a cooperative and participatory manner;ethnographic ${ }^{19}$, whose purpose is the study of people in their own environment through the use of procedures such as in-depth interviews and participant observation.

The researches that compose the corpus of this study were also grouped in four thematic axes according to their objectives, namely: 1 . Discuss the teaching and learning process of written PL for the deaf; 2. Analyze the written production of deaf students; 3 . Reflect on the role of sign language, signed or written in the process of acquiring the written Portuguese language; 4. Critically analyze the teaching of PL for the deaf, based on the bilingual educational philosophy and the legal documents governing the education of these students.

It is important to point out that it was also possible to find studies that went through more than one thematic axis. However, it was decided to consider the main focus of each study. 


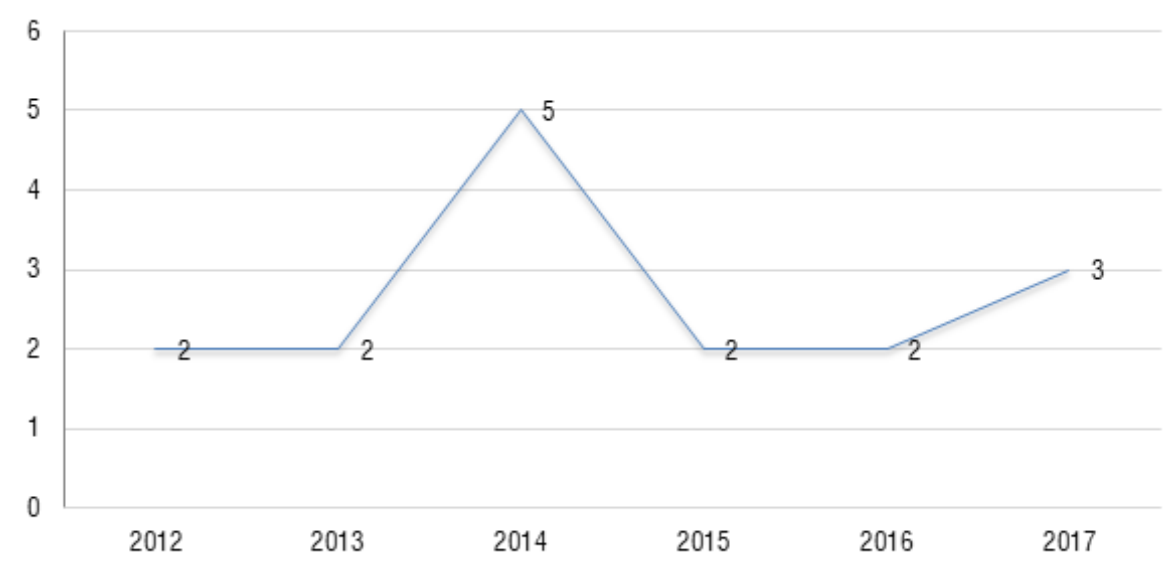

Figure 1. Number of scientific studies that deal with Portuguese language teaching for the deaf, published in the period from 2012 to 2017

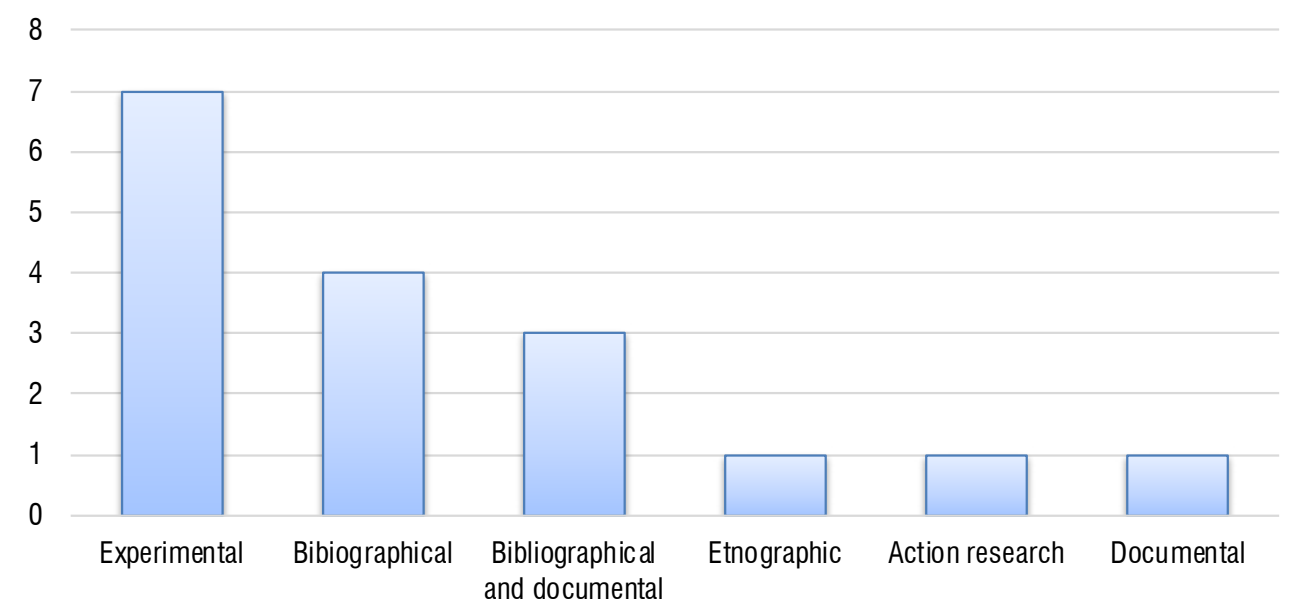

Figure 2. Distribution of scientific studies that deal with Portuguese language teaching for the deaf, by type, published between 2012 and 2017

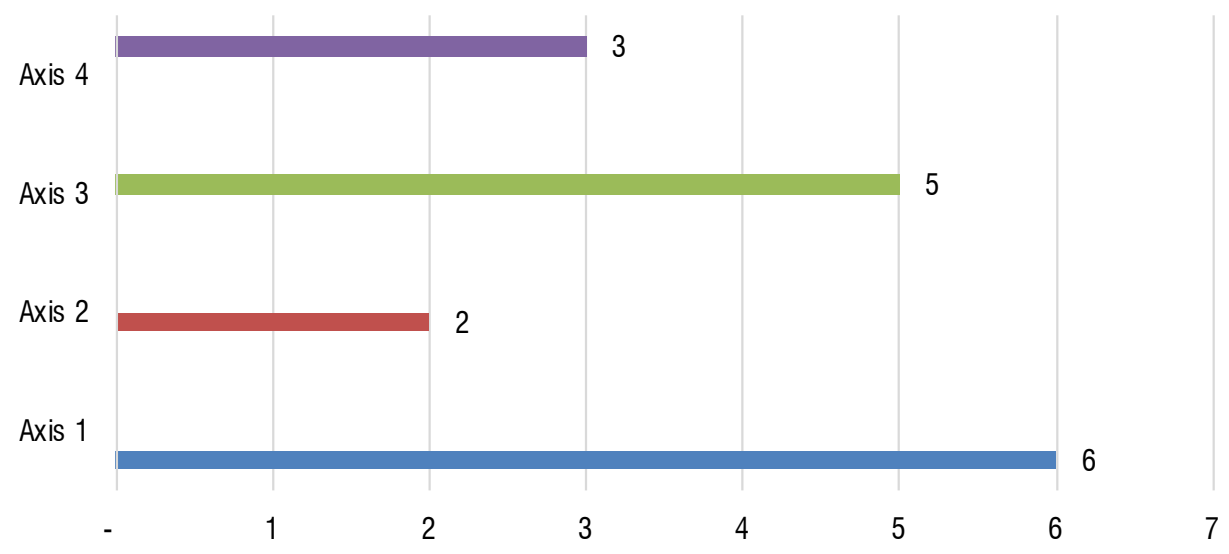

- Analyze the teaching of PL, the bilingual educational philosophy and the main legal documents

$\square$ Reflect on the role of sign language in the process of acquiring writing

- Investigate written productions

$\square$ Discuss the process of theaching the learning of written portuguese

Figure 3. Number of scientific studies that deal with Portuguese language $(\mathrm{PL})$ teaching for the deaf, published during the period from 2012 to 2017 , categorized by thematic axis 


\begin{tabular}{|c|c|c|c|c|c|c|}
\hline Study & Authors & Researchers area & Description & Type & $\begin{array}{c}\begin{array}{c}\text { Thematic } \\
\text { axis }\end{array} \\
\end{array}$ & Journal / Year \\
\hline $\begin{array}{l}\text { 1. Influence of the type of } \\
\text { visual stimulus in the written } \\
\text { production of deaf sign users } \\
\text { without complaints of writing } \\
\text { changes. }^{7}\end{array}$ & $\begin{array}{l}\text { Rodrigues M GG, } \\
\text { Abdo AG R, } \\
\text { Cárnio MS. }\end{array}$ & $\begin{array}{l}\text { Physiotherapy / Speech } \\
\text { Therapy / Occupational } \\
\text { therapy }\end{array}$ & $\begin{array}{l}\text { Analyzes the influence of the } \\
\text { type of visual stimulus on the } \\
\text { written production of deaf } \\
\text { signers without complaints of } \\
\text { writing changes. }\end{array}$ & Experimental & 2 & $\begin{array}{l}\text { Revista da } \\
\text { Sociedade Brasileira } \\
\text { de Fonoaudiologia, } \\
2012 .\end{array}$ \\
\hline $\begin{array}{l}\text { 2. Transfer of ordinal functions } \\
\text { through equivalent stimulus } \\
\text { classes in the deaf. }{ }^{24}\end{array}$ & $\begin{array}{l}\text { Resende AAC, } \\
\text { Elias NC, GoyosC. }\end{array}$ & Psychology & $\begin{array}{l}\text { Investigates the transfer } \\
\text { of ordinal functions to } \\
\text { new sequences after the } \\
\text { establishment of four } \\
\text { equivalent stimulus classes, } \\
\text { followed by the teaching of a } \\
\text { single sequence. }\end{array}$ & Experimental & 1 & $\begin{array}{l}\text { Acta } \\
\text { comportamentalia: } \\
\text { revista latina } \\
\text { de análisis del } \\
\text { comportamiento, } \\
2012 .\end{array}$ \\
\hline $\begin{array}{l}\text { 3. Bilingual education for the } \\
\text { deaf and inclusion according to } \\
\text { the National Policy on Special } \\
\text { Education and Decree } n^{0} \\
5.626 / 05 . .^{11}\end{array}$ & Lodi ACB. & Education / Linguistics & $\begin{array}{l}\text { Seeks to unveil the different } \\
\text { meanings of bilingual } \\
\text { education and inclusion in } \\
\text { the National Policy on Special } \\
\text { Education in the perspective } \\
\text { of inclusive education and } \\
\text { in Decree } 5626 / 05 \text { in light } \\
\text { of Bakhtin's discursive- } \\
\text { enunciative theory. }\end{array}$ & $\begin{array}{l}\text { Bibliographical } \\
\text { / documental }\end{array}$ & 4 & $\begin{array}{c}\text { Educação e } \\
\text { Pesquisa, } 2013 .\end{array}$ \\
\hline $\begin{array}{l}\text { 4. The Brazilian signs language } \\
\text { and the teaching of the deaf } \\
\text { student. }^{8}\end{array}$ & $\begin{array}{l}\text { Ribeiro HM, } \\
\text { Nascimento AP. }\end{array}$ & Education & $\begin{array}{l}\text { Analyzes the importance } \\
\text { of sign language in the } \\
\text { educational development of } \\
\text { students in the regular school } \\
\text { system. }\end{array}$ & Bibliographical & 3 & Nucleus, 2013. \\
\hline $\begin{array}{l}\text { 5. Collective learning of the } \\
\text { Portuguese language for the } \\
\text { deaf through sign language } \\
\text { interactions. }{ }^{5}\end{array}$ & Pires VOD. & Linguistics & $\begin{array}{l}\text { Analyzes the interactions } \\
\text { between deaf students during } \\
\text { the development of a didactic } \\
\text { unit that encouraged them to } \\
\text { write a letter of complaint in } \\
\text { Portuguese about their school. }\end{array}$ & Experimental & 1 & $\begin{array}{l}\text { Revista Brasileira } \\
\text { de Linguística } \\
\text { Aplicada, } 2014 .\end{array}$ \\
\hline $\begin{array}{l}\text { 6. The teaching-learning } \\
\text { process of reading in a class } \\
\text { of deaf students: an analysis } \\
\text { of the interactions mediated by } \\
\text { Libras. }^{10}\end{array}$ & Silva GM. & Education / Linguistics & $\begin{array}{l}\text { Analyzes the practices } \\
\text { of reading texts in } \\
\text { Portuguese,constructed by } \\
\text { deaf students and a hearing } \\
\text { teacher, observing the way } \\
\text { these participants use the } \\
\text { Brazilian Sign Language } \\
\text { (Libras) to read and refer to the } \\
\text { written text. }\end{array}$ & Ethnographic & 3 & $\begin{array}{l}\text { Revista Brasileira } \\
\text { de Linguística } \\
\text { Aplicada, 2014. }\end{array}$ \\
\hline $\begin{array}{l}\text { 7. Attribution of meaning to } \\
\text { writing by deaf children using } \\
\text { sign language. }{ }^{28}\end{array}$ & $\begin{array}{c}\text { Silva TSA, } \\
\text { Bolsanello MA. }\end{array}$ & Education / Psychology & $\begin{array}{l}\text { Identifies different orientations } \\
\text { present in the methodological } \\
\text { propositions of teaching } \\
\text { writing for deaf sign language } \\
\text { users, assumed in bilingual } \\
\text { education. }\end{array}$ & Bibliographical & 3 & $\begin{array}{c}\text { Educar em } \\
\text { Revista, } 2014 .\end{array}$ \\
\hline $\begin{array}{l}\text { 8. Bilingualism and linguistic } \\
\text { policies in Brazil: from } \\
\text { monolingual illusion to } \\
\text { plurilingual reality. }{ }^{29}\end{array}$ & $\begin{array}{l}\text { Preuss E0, } \\
\text { Álvares MR. }\end{array}$ & Linguistics & $\begin{array}{l}\text { Discusses the linguistic } \\
\text { policies in force in Brazil, } \\
\text { problematizing notions } \\
\text { of bilingualism explicit or } \\
\text { underlying some official } \\
\text { documents. }\end{array}$ & $\begin{array}{l}\text { Bibliographical } \\
\text { / documental }\end{array}$ & 4 & $\begin{array}{c}\text { Acta Scientiarum. } \\
\text { Language and } \\
\text { Culture (UEM), } 2014 .\end{array}$ \\
\hline $\begin{array}{l}\text { 9. The teaching of Portuguese } \\
\text { as a second language for } \\
\text { the deaf: theoretical and } \\
\text { methodological principles. }{ }^{27}\end{array}$ & Pereira MCC. & Linguistics & $\begin{array}{l}\text { Discusses the teaching of the } \\
\text { Portuguese language that has } \\
\text { been taught for deaf students, } \\
\text { which prohibits the use of } \\
\text { sign language and which is } \\
\text { based on the conception of } \\
\text { language as code; the teaching } \\
\text { methodology adopted and } \\
\text { its effects on the reading and } \\
\text { writing of the deaf. }\end{array}$ & Documental & 2 & $\begin{array}{l}\text { Educar em } \\
\text { Revista, № spe-2 } \\
2014 .\end{array}$ \\
\hline
\end{tabular}




\begin{tabular}{|c|c|c|c|c|c|c|}
\hline Study & Authors & Researchers area & Description & Type & $\begin{array}{c}\text { Thematic } \\
\text { axis }\end{array}$ & Journal / Year \\
\hline $\begin{array}{l}\text { 10. Essentialization of deafness } \\
\text { in lack of speech of the } \\
\text { linguistic status of Libras and } \\
\text { educational implications. }{ }^{9}\end{array}$ & Martins ALB. & Linguistics & $\begin{array}{l}\text { Problematizes the } \\
\text { essentialization of deafness } \\
\text { from discursivizations that } \\
\text { defend an extended linguistic } \\
\text { status for sign languages, } \\
\text { linking this claim to the } \\
\text { implications of an inlcusivist } \\
\text { scenario of national education. }\end{array}$ & Bibliographical & 3 & $\begin{array}{c}\text { Domínios de } \\
\text { Lingu@gem, } 2015 .\end{array}$ \\
\hline $\begin{array}{l}\text { 11. Consequences of the } \\
\text { Late Acquisition of the } \\
\text { Brazilian Sign Language in } \\
\text { Reading Comprehension of } \\
\text { the Portuguese Language, as } \\
\text { a Second Language, in Deaf } \\
\text { Subjects. }\end{array}$ & Silva SGL. & Linguistics & $\begin{array}{l}\text { Investigates the consequences } \\
\text { of the late acquisition of } \\
\text { sign language in the reading } \\
\text { comprehension in Portuguese } \\
\text { language as second language } \\
\text { by signing deaf of the Brazilian } \\
\text { sign language. }\end{array}$ & Experimental & 3 & $\begin{array}{c}\text { Revista Brasileira de } \\
\text { Educação Especial, } \\
2015 .\end{array}$ \\
\hline $\begin{array}{l}\text { 12. Pedagogical practices: } \\
\text { written language and deafness. }{ }^{6}\end{array}$ & Pereira MMGDPN. & Education & $\begin{array}{l}\text { Analyzes the pedagogical } \\
\text { practices of teaching written } \\
\text { Portuguese language, in } \\
\text { special schools of bilingual } \\
\text { orientation (Brazilian sign } \\
\text { language and Portuguese } \\
\text { language). }\end{array}$ & Experimental & 1 & $\begin{array}{c}\text { Journal of } \\
\text { Research in Special } \\
\text { Educational Needs, } \\
2016 .\end{array}$ \\
\hline $\begin{array}{l}\text { 13. Portuguese for the deaf and } \\
\text { digital technologies. }{ }^{22}\end{array}$ & $\begin{array}{l}\text { Castro FGAS, } \\
\text { Calixto HRS. }\end{array}$ & Education / Linguistics & $\begin{array}{l}\text { Analyzes pedagogical activities } \\
\text { proposed by Quadros and } \\
\text { Schmiedt (2006) and relates } \\
\text { to discussions about the } \\
\text { use of digital technologies in } \\
\text { Portuguese language teaching } \\
\text { for the deaf. }\end{array}$ & Bibliographical & 1 & $\begin{array}{l}\text { Journal of } \\
\text { Research in Special } \\
\text { Educational Needs, } \\
2016 .\end{array}$ \\
\hline $\begin{array}{l}\text { 14. Deaf pedagogy and } \\
\text { bilingualism: points and } \\
\text { counterpoints in the perspective } \\
\text { of an inclusive education. }{ }^{2}\end{array}$ & $\begin{array}{c}\text { Streiechen E.M, } \\
\text { Krause-Lemke C, } \\
\text { Oliveira JP; Cruz GC. }\end{array}$ & Education / Linguistics & $\begin{array}{l}\text { Discusses the inclusion of } \\
\text { deaf people in classrooms of } \\
\text { regular schools, in the light of } \\
\text { the legal order in force, which } \\
\text { is based on the inclusive } \\
\text { educational perspective. }\end{array}$ & $\begin{array}{l}\text { Bibliographical } \\
\text { / documental }\end{array}$ & 4 & $\begin{array}{l}\text { Acta Scientiarum. } \\
\text { Education (UEM), } \\
2017 .\end{array}$ \\
\hline $\begin{array}{l}15 \text { Considerations on deaf } \\
\text { education and technologies } \\
\text { from the analysis of the } \\
\text { teaching strategies of a deaf } \\
\text { teacher. }\end{array}$ & $\begin{array}{l}\text { Nogueira A, } \\
\text { Cabello J. }\end{array}$ & Education / Linguistics & $\begin{array}{l}\text { Highlight some of the ways } \\
\text { in which a deaf teacher has } \\
\text { established relationships with } \\
\text { a digital material and proposed } \\
\text { the course of his class together } \\
\text { with a group of deaf children, } \\
\text { in order to contribute to the } \\
\text { already existing discussions } \\
\text { that relate the field of deafness } \\
\text { to the technologies. } \\
\end{array}$ & Experimental & 1 & $\begin{array}{c}\text { Texto Livre: } \\
\text { Linguagem e } \\
\text { Tecnologia, } 2017 .\end{array}$ \\
\hline $\begin{array}{l}\text { 16. Application of a Program } \\
\text { of Teaching Words in Libras } \\
\text { Using Augmented Reality } \\
\text { Technology. }{ }^{23}\end{array}$ & $\begin{array}{l}\text { Carvalho D, } \\
\text { Manzini EJ. }\end{array}$ & Education & $\begin{array}{l}\text { Verifies the effectiveness of } \\
\text { a program of teaching words } \\
\text { in Libras using software with } \\
\text { augmented reality technology } \\
\text { and evaluates the initial and } \\
\text { final repertoire of students with } \\
\text { deafness, referring to groups } \\
\text { of words taught through the } \\
\text { application of a teaching } \\
\text { program with augmented } \\
\text { reality technology. }\end{array}$ & Experimental & 1 & $\begin{array}{l}\text { Revista Brasileira } \\
\text { de Educação } \\
\text { Especial, } 2017 .\end{array}$ \\
\hline
\end{tabular}

Figure 4. Synthesis of the studies that approach the teaching of the Portuguese language for the deaf, published between 2012 and 2017 


\section{LITERATURE REVIEW}

Bilingual education for deaf people is nowadays characterized as the most appropriate educational philosophy, considering that it respects the deaf person's condition and visual experience as a constituent of a singular culture, without, however, disregarding the necessary school learning of Portuguese. It demands the design of a language policy that defines the participation of the two languages in the school throughout the schooling process in order to confer legitimacy and prestige of Libras as the curricular and constituent language of the deaf person ${ }^{21}$. The appropriation of this cultural artifact becomes important for these subjects, since it allows access to the knowledge historically constructed by humanity.

In this perspective, sign language occupies the first language space (L1), since it is the language most accessible to the deaf, since its acquisition process happens without physiological impediments and its appropriation also contributes to the cognitive development of deaf children.

PL occupies the space of second language, considering that it is usually acquired after the sign language, through a systematic process experienced in educational institutions. In this sense, it is important to highlight that the learning of this language (PL) occurs, preferably, in its written modality. In view of this, scientific research is dedicated to clarifying the aspects involved in the teaching and learning process of written $\mathrm{PL}$ for the deaf and, in this way, to contribute to the reduction of existing linguistic barriers.

The integrative literature review was initiated with a survey of the number of publications in each year, within the determined time frame, between 2012 and 2017 (Figure 1). This action allowed us to identify the period in which the theme generated the most interest to the researchers, year 2014, as well as to verify that, in 2017, despite not having the data for the full year, the interest in the subject increased again.

Regarding the type of study (Figure 2), it was identified that most of the researchers chose to use the experimental research, since it allows a closer approximation to its object. This does not imply that the other methods are not used or even adequate to the study of the subject, but what can be inferred is that the experimental method provides a greater number of data to the researcher and, consequently, a greater contribution to the advancement in understanding the phenomenon.

The identification of the area of academic training of the researchers (Figure 4) allowed us to visualize the areas that are interested in the subject of Portuguese Language teaching for the deaf, evidencing that education and linguistics are the ones that are most dedicated to find answers to this problem, without disregarding the contributions of speech therapy and psychology.

Turning the focus of this review to the thematic axes (Figure 3), the six studies that make up the first group have the bias that points to the discussion of the teaching and learning process of written PL for the deaf ${ }^{4-6,22-24}$. In this group, we identified some studies that sought to present didactic strategies that aimed to facilitate the access of the deaf to written LP. Among them, three surveys ${ }^{4,22,23}$ have used digital information and communication technologies to achieve this goal, namely: digital book ${ }^{4}$, transposition ${ }^{22}$ of some activities proposed in a publication by $\mathrm{MEC}^{25}$ for the digital sphere and augmented reality ${ }^{23}$ for the teaching of words. In the research ${ }^{4}$ that used a digital book, the authors concluded that, based on the potentialities arising from the technologies, it is believed that it is possible to produce new meanings in the work with the most diverse language practices in the school context; on the other hand, school practices already considered canonical (and widely diffused and questioned), which in many cases end up being merely reproduced in digital media and evidence school doings that differ greatly from the ways in which children and young people (and the teachers themselves) have been reading and writing in non-school contexts by appropriating the most diverse digital resources ${ }^{4}$.

Still using the digital technologies, a study ${ }^{22}$ was carried out that reflected on the possibility of transposing to the digital medium, memory play and crosswords in order to facilitate the teaching of words. With this transposition, scholars understand that activities (memory play and crosswords), being used concomitantly with digital information and communication technologies, help in the application of these resources during classes, since these are instruments that facilitate the teaching of LP for the deaf ${ }^{22}$.In this study, although the proposal is restricted to the teaching of isolated words, the researchers emphasize the importance of working to expand students' vocabulary from texts, assuming an interactionist perspective of language.

Also in this axis, a study ${ }^{5}$ investigated, from the theory of scaffolding ${ }^{26}$, the collective learning of PL mediated by the sign language. In this research, considering that PL allows access to cultural goods (literature and education), information through the media, 
preparation for the exercise of citizenship, enabling the individual to participate politically in a society where everything is expressed and regulated in $\mathrm{PL}^{5}$, the scholars believe that the deaf people, during the process of collective production of written texts, interacting through sign language, construct the knowledge about this language from a collective scaffolding. In this process, what each one knows is added and this knowledge becomes dynamic, solves problems, builds new possibilities collectively and gives more autonomy to each individual ${ }^{5}$.

In short, it is evident in this axis that the reflections on the teaching of PL for the deaf can follow different paths. However, the contributions of these studies may help educators better understand the phenomenon and, consequently, strengthen their practice.

The second axis consists of two works ${ }^{7,27}$ that investigate the written productions of deaf students. These studies analyzed texts/productions from images. The first $^{7}$ analyzed the texts produced by deaf students from two visual stimuli, action figure and sequence of figures. The researchers concluded that neither of the two types of stimuli, be it an action figure or a sequence of figures, provide better writing performance of deaf signers without complaints of writing changes for most aspects analyzed ${ }^{7}$. In the second ${ }^{22}$, student productions from an image were also analyzed. However, in this case, the teacher carried out collective and individual productions during the process of construction of the productions.

What drew attention to this axis was the strategy used to lead the students to produce texts from images, considering that such a strategy disregards the aspects involved in a textual production, that is, the production conditions. This implies that, outside school, the productions of texts happen from the need for interaction between people. It is important to emphasize that the school should not disregard this fact in the classes of textual production. In this sense, it is possible to affirm that the result obtained, neither of the two types of stimuli provided a better performance ${ }^{7}$, could have happened due to the inappropriate choice of instruments for the data collection, since this type of textual production limits the potentialities of the students so that one does not have a faithful picture of their knowledge in relation to writing.

The third thematic axis was composed of five studies $^{3,8-10,28}$ that proposed to reflect on the role of sign language (signed or written) in the process of acquisition of written PL. According to the authors, the acquisition of sign language as the first language will provide a linguistic and cognitive basis for deaf students to learn written PL as a second language. However, the fact that deaf people acquire the sign language late can make it difficult to learn this second language.

From the study of the consequences of the late acquisition of sign language, the researcher ${ }^{3}$ considers that the age factor of acquisition of the Brazilian sign language by deaf individuals showed a significant interference in the reading comprehension of PL as a second language. However, there are other factors to be considered: contact with other deaf people who are fluent; support and motivation of the family in the use of both languages (Libras and PL); the presence of sign language during their school trajectory; teaching methodologies of PL that help the deaf to discover their own strategies for building meaning, to detect the differences in the modalities of the languages produced, the particularities of the Portuguese language in terms of sign language and what is common to both ${ }^{3}$.

In relation to teaching methodology, researchers ${ }^{8}$ argue that the procedure for a deaf person to learn $\mathrm{PL}$ in its written modality is the same as a hearer's experience of learning a second language. Before this learning becomes effective, the deaf person should be granted, according to the objective of the bilingual approach, first with the acquisition of Sign Language as the first language, which will enable them to construct their subjectivity, and provide linguistic support so that he learns the Portuguese language.

One point worth mentioning is that only two studies $^{9,28}$ of this axis pointed to the existence of sign writing or direct visual writing. One of them ${ }^{28}$ argues that the sign writing, as a system full of meanings, seems to constitute an additional possibility of conferring on the deaf maximized conditions for the development of their higher functions of thought, as well as providing means of approximation with the major writing system of their country, which is the alphabetic writing ${ }^{28}$. However, the second ${ }^{9}$ assumes a not-so-optimistic view of this writing stating that it is still incipient and unpromising to expect a written code applied to sign writing to "catch" among the "speakers" of sign languages. It would be like "inventing the wheel" to alphabetize the deaf in "their own language".

What is clear from the position of these scholars in relation to writing in signs is that there is not yet a consensus about its importance in the process of appropriation of writing in the Portuguese language, indicating the need to carry out new research that deals 
with this topic in order to validate or not its importance in relation to this construction.

There were also divergences regarding the role of the school in the construction of the linguistic identity of these students, since there are researchers ${ }^{27}$ who argue that the school should enable, especially in the case of children of hearing parents, the acquisition of the Brazilian Sign Language, which will occur in the interaction with fluent users of that language, preferably deaf, who, in using and interpreting the movements and statements of deaf children in sign language, insert them into the linguistic-discursive functioning of that language. And, in the face of this highly pervasive perspective among deaf education researchers, one researcher says that lately the school has assumed responsibilities that go beyond working with the knowledge associated with a written production of a learned character. Its linguistic commitment, however, even in the case of deaf students, is mainly and primarily linked to the Portuguese language. What the author emphasizes is that it would not fit the school, par excellence, the promotion and concern for the linguistic identity of deaf children.

This implies that there is still no consensus regarding the role of the school through the linguistic singularity of these students, since, for the most part, because they are the children of hearing parents, they arrive at school without a constituted language, making it difficult to perform better at school in relation to the teaching and learning of the Portuguese language. This situation still needs to be addressed by the scholars of the area.

In relation to the fourth axis, composed of studies $^{11,12,29}$ in which the researchers critically analyze Portuguese language teaching for the deaf, based on the bilingual educational philosophy and the main legal documents ${ }^{1,2,21,30}$ that govern the education of these students, it was possible to identify that the three proposals that make up this axis are unanimous when they affirm that there is no consonance between the policies of school inclusion and the linguistic policies directed to deaf students. This situation is evident in the definition of the role of the languages involved in their educational process. While in linguistic policies Libras should be the language of instruction and Portuguese the second language, in inclusive policies the language of instruction is the Portuguese language and Libras is configured as an instrument for access to the major language.
According to the researchers, there is a significant difference in the meanings of bilingual education for the deaf in the constitution of the texts of the National Policy on Special Education in the Perspective of Inclusive Education and of the Decree 5626/05 that regulates the laws that deal with the Brazilian Sign Language (Law 10.436/2002 and Law 10.098/2000 - article 18). While in this last document, Libras acquires a central role in all the education of deaf people, and Portuguese in its written form is treated as a second language, the policy moves Libras from its first language status to deaf people, marking hegemony of the Portuguese language throughout the educational process ${ }^{11}$.

Another point highlighted in the studies of this axis is the fact that inclusive policies disregard the existing language barriers between deaf and hearing, since MEC's policy advocates that deaf students study together with hearing students. But the communicative barriers encountered by the whole community prevent the teaching/learning process from actually occurring. And if there are barriers, there is no inclusion ${ }^{12}$.

In short, from the studies of this axis, it is clear that policies for inclusive education ${ }^{30}$ of students with disabilities, including the deaf, prevent the consolidation of the language policies that guarantee them a bilingual education, with Libras as L1 and Portuguese as $L 2$, since in the inclusive system, despite conceiving the presence of sign language, the Portuguese language gains a prominent place throughout the educational process, generating an asymmetry between languages. This leads us to believe that there is a dissonance between the precepts of these policies and that the majority of the Brazilian inclusive schools ${ }^{15}$ may be experiencing a pseudo-bilingual practice ${ }^{31}$.

The importance of the teacher's role in reflections on the acquisition of writing by deaf students, as well as the need for greater investment in the training of these professionals, was not restricted to only one of the axes, since nine studies mention this subject matter. Therefore, in spite of the legal guidelines on the training of teachers to work with deaf students, contained in Decree 5626/05, a school daily life with impoverished practices was still found, in which text comprehension activities were reduced to a mechanical reading without reflection ${ }^{6}$.

This problem was also identified in another study that, after analyzing the extension of the texts produced by these students, led the scholars ${ }^{18}$ to affirm that the production of texts with isolated phrases and short corroborates the discussion about the difficulty of 
the deaf in constructing texts in written Portuguese, both for the distancing of the language and for the teachers' lack of preparation to work with the deaf in the classroom?

In this way, what can be perceived after this work is that, although the studies approach the theme by different optics, they all set out to reflect on the main barriers in the teaching and learning process of the written Portuguese language by deaf people, as well as to propose outcomes to overcome them, in order to ensure that the deaf can appropriate this cultural asset that belongs to all Brazilians, the written Portuguese language.

\section{CONCLUSION}

The main purpose of this study was to identify the contributions of scientific research in order to overcome barriers identified in the process of teaching and learning written Portuguese language (PL) for deaf students. For that, an integrative review of the literature of the articles published, in the last five years, was carried out in the databases of Capes and Scielo.

After analyzing the articles that compose this literature review, it was found that the deaf still find many barriers to the acquisition of L2 despite having guaranteed by law the access to bilingual education, in which Libras is configured as L1 and the written Portuguese language as L2, which would allow them access to knowledge historically constructed by humanity, as well as interact in the hearing society, exercising their rights autonomously, thus manifesting their subjectivity.

From this perspective, it was identified, in the light of such studies, that the late acquisition of a language, the lack of adequate teacher training, the difficulty of communication between the deaf and normally hearing pupils in inclusive schools, as well as the divergences between educational and linguistic policies which guide education for these subjects, are the main obstacles that still exist for the teaching and learning of Portuguese.

In view of this, the scholars indicate some of the outcomes to overcome the barriers presented, such as: the collective production of texts mediated by Libras; the use of digital resources in Portuguese language classrooms; the review of educational policies; early acquisition of Sign Language by the deaf; the teaching of Libras in its written form (Sign Writing), as well as the investment in teacher training that contemplates the specificities of the teaching of writing for the deaf, as a second language.

In summary, it is concluded that the studies analyzed, in some way, offered valuable contributions to rethink the teaching of PL for the deaf, since they allowed to visualize the theme from different angles and, therefore, have a clearer idea of the dimension of the aspects that surround this scenario.

\section{REFERENCES}

1. Brasil. Lei 10.436/02, de 24 de abril de 2002. Dispõe sobre a Língua Brasileira de Sinais - Libras e dá outras providências. Brasília, DF, 2002. http://www. planalto.gov.br/ccivil_03/leis/2002/10436.htm

2. Brasil.Decreto 5.626, de 22 de dezembro de 2005. Regulamenta a Lei $10.436 / 2002$ e o art. 18 da Lei 10.098/2000. Brasília, DF, 2005.http://www. planalto.gov.br/ccivil_03/_Ato2004-2006/2005/ Decreto/D5626.htm

3. Silva SGL. Consequências da aquisição tardia da língua brasileira de sinais na compreensão leitora da língua portuguesa, como segunda língua, em sujeitos surdos. Rev Bras Educ Esp. 2015;21(2):275-88.

4. Nogueira A, Cabello J. Considerações sobre educação de surdos e tecnologias a partir da análise das estratégias de ensino de professor surdo. Text Liv Ling Tec. 2017;0(1):242-56.

5. Pires VOD. A aprendizagem coletiva de língua portuguesa para surdos através das interações em língua de sinais. Rev Bras Ling Aplic. 2014;14(4):987-1014.

6. Pereira MMGDPN. Práticas pedagógicas: língua escrita e surdez. J. Res Spec Educ Needs. 2016;16(1):889-93.

7. Rodrigues MGG, Abdo AGR, Cárnio MS. Influência do tipo de estímulo visual na produção escrita de surdos sinalizadores sem queixas de alterações na escrita. Rev Soc Bras Fonoaudiol. 2012;17(2):208-15.

8. Ribeiro HM, Nascimento AP. A língua brasileira de sinais e o ensino do aluno surdo. Nucleus. 2013;10(2):27-37.

9. Martins ALB. Essencialização da surdez em discursivizações do status linguístico da Libras e implicações educacionais. Dom Ling. 2015;9(1):217-40.

10. Silva GM. O processo de ensino-aprendizagem da leitura em uma turma de alunos surdos: uma 
análise das interações mediadas pela Libras. Rev Bras Ling Aplic. 2014;14(4):905-34.

11. Lodi ACB. Educação bilíngue para surdos e inclusão segundo a Política Nacional de Educação Especial e o Decreto no 5.626/05. Educ Pesq. 2013;39(1):49-63.

12. Streiechen EM, Krause-Lemke C, Oliveira JP, Cruz GC. Pedagogia surda e bilinguismo: pontos e contrapontos na perspectiva de uma educação inclusiva. Acta Scient Educ. 2017;39(1):91-101.

13. Koch IV, Elias VM. Ler e compreender: os sentidos do texto. São Paulo: Contexto, 2009.

14. Antunes I. Textualidade: noções básicas e implicações pedagógicas. São Paulo: Parábola, 2017.

15. Skliar C. A localização política da educação bilíngue para surdos. In: (Org). Atualidade da educação bilíngue para surdos: processos e projetos pedagógicos. Vol. (2.) Porto Alegre: Mediação, 1999. p. 7-14.

16. Pereira MCC (org). Libras conhecimento além dos sinais. São Paulo: Pearson, 2011.

17. Vygotsky LS. A formação social da mente: o desenvolvimento dos processos psicológicos superiores. 7a. ed. São Paulo: Martins Fontes, 2007.

18. Hohendorff JV. Como escrever um artigo de revisão de literatura. In: Koller SH, Couto MCPP, Hohendorff JV (orgs). Manual de produção científica. Porto Alegre: Penso, 2014. p.39-54

19. Gil AC. Como elaborar projetos de pesquisa. 6a. ed. São Paulo: GEN/Atlas, 2017.

20. Thiollente M. Metodologia da pesquisa-ação. São Paulo: Cortez, 1985, Apud Gil AC. Como elaborar projetos de pesquisa. 6a . ed. São Paulo: GEN/ Atlas, 2017.

21. Brasil, MEC/SECADI. Relatório sobre a política linguística de educação bilíngue: Língua Brasileira de Sinais e Língua Portuguesa. Brasília, DF, 2014.

22. Castro FGAS, Calixto HRS. Português para surdos e as tecnologias digitais. J. Res Spec Educ Needs. 2016;16(1):870-5.

23. Carvalho D, Manzini EJ. Aplicação de um programa de ensino de palavras em Libras utilizando tecnologia de realidade aumentada. Rev Bras Educ Esp. 2017;23(2):215-32.

24. Resende AAC, Elias NC, Goyos C. Transferência de funções ordinais através de classes de estímulos equivalentes em surdos. Acta comport: Rev lat anal comport. 2012;20(3):317-28.
25. Quadros RM, Schmiedt MLP. Ideias para ensinar português para surdos. Brasília: MEC, SEESP, 2006.

26. Wood D, Bruner J, Roos G. The role of tutoring in problem solving. J Child Psyc. 1976;17:89-100.

27. Pereira MCC. O ensino de português como segunda língua: princípios teóricos e metodológicos. Educ Rev. 2014;edição especial(2):143-57.

28. Silva TSA, Bolsanello MA. Atribuição de significado à escrita, por crianças surdas usuárias de língua de sinais. Educ Rev. 2014; edição especial(2):129-42.

29. Preuss EO, Álvares MR. Biliguismo e políticas linguísticas no Brasil: da ilusão monolíngue à realidade plurilíngue. Acta Scient Lang Cult. 2014;36(4):403-14.

30. Brasil. Política Nacional da Educação Especial na Perspectiva da Educação Inclusiva. Brasília, DF, 2008. http://portal. mec.gov.br/index.php?option $=c o m$ docman\&view $=$ download\&alias $=16690$-politicanacional-de-educacao-especial-na-perspectiva-daeducacao-inclusiva-05122014\&ltemid $=30192$

31. Guedes BS. A língua de sinais na escola inclusiva: estratégias de normalização da comunidade surda. In: Lopes MC, Hattge MD (orgs). Inclusão escolar: conjunto de práticas que governam. Belo Horizonte: Autêntica Editora, 2009. p. 33-49. 